\title{
Hormonemate, a New Cytotoxic and Apoptosis-Inducing Compound from the Endophytic Fungus Hormonema dematioides. I. Identification of the Producing Strain, and Isolation and Biological Properties of Hormonemate H $^{\S}$
}

Patrick Filipa ${ }^{\mathrm{a}}$, Roland W. S. Weber ${ }^{\mathrm{b}}$, Olov Sterner ${ }^{\mathrm{c}}$, and Timm Anke ${ }^{\mathrm{a}, \mathrm{b}^{*}}$

a Institute of Biotechnology and Drug Research (IBWF e. V.), Erwin-Schrödinger-Str. 56,

D-67663 Kaiserslautern, Germany. Fax +496312052999. E-mail: anke@rhrk.uni-kl.de

b Department of Biotechnology, University of Kaiserslautern, Paul-Ehrlich-Str. 23,

D-67663 Kaiserslautern, Germany

c Department of Organic and Bioorganic Chemistry, Lund University, P. O. Box 124, S-22100 Lund, Sweden

* Author for correspondence and reprint requests

Z. Naturforsch. 58c, 547-552 (2003); received April 9/May 16, 2003

In a search for new fungal compounds inducing apoptosis of the colon cancer derived cell line COLO-320, hormonemate (1) was purified from fermentations of an endophytic fungus isolated from living needles of a Pinus species. The producing strain was identified as Hormonema dematioides by microscopy and ITS rDNA sequence analysis. The structure of hormonemate was determined by spectroscopic methods. The compound exhibited cytotoxic effects against the human colon tumor cell lines COLO-320, DLD-1 and HT-29 as well as five other human cell lines (HL-60, JURKAT, HEP-G2, MCF-7, HeLa S3). It also induced apoptosis in COLO-320 cells as detected by a caspase-activity assay and morphological changes, and it triggered morphological and physiological differentiation of HL-60 cells into granulocytes, which subsequently died by apoptosis.

Key words: Hormonemate, Endophyte, Hormonema dematioides

\section{Introduction}

Among the promising sources of new bioactive compounds are fungi growing inside plants without producing apparent symptoms and which for that reason have remained unnoticed for a long time. Recent studies, however, have shown that most plants are associated with more than 10 endophytic fungi, resulting in an estimated number of over 1 million endophytic species worldwide (Hawksworth, 1991). Among the prominent natural products isolated so far is taxol which is produced not only by Taxus spp. but also by endophytes isolated from Taxus brevifolia and other plants (Strobel, 2002).

Since colorectal cancer is particularly recalcitrant to chemotherapeutic intervention, new compounds interfering with its growth and the development of metastases are urgently needed. In a screening of fungal cultures for cytostatic, cyto-

Abbreviations: Ac, acetyl; AMC, 7-amido-4-methylcoumarin; CHO, chloromethylketone; DEVD, Asp-GluVal-Asp.

$\S$ This paper is dedicated to Professor Dr. Wolfgang Steglich on occasion of his $70^{\text {th }}$ birthday. toxic or apoptosis-inducing activities against the colon-cancer derived cell line COLO-320 a new compound, hormonemate (1, Fig. 1), was detected and isolated from fermentations of the endophytic fungus Hormonema dematioides. In the following we wish to describe the producer as well as the production, isolation and biological activities of $\mathbf{1}$. The structure elucidation will be subject of a separate paper (Sterner et al., in preparation).

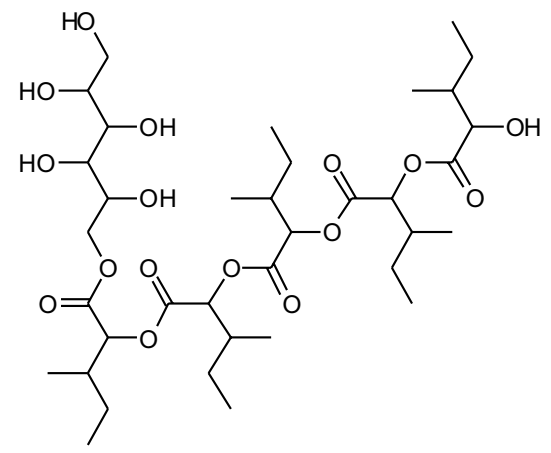

Fig. 1. Structure of hormonemate (1). 


\section{Materials and Methods}

\section{Producing organism}

The producing strain E99156 was isolated as a symptomless endophyte from the needle base of a Pinus sp. collected in Portugal at an altitude of $1100 \mathrm{~m}$. Isolation was from surface-sterilized plant material ( $1 \mathrm{~min} 70 \%$ ethanol, $3 \mathrm{~min} 5 \%$ sodium hypochlorite, $30 \mathrm{~s} 70 \%$ ethanol) onto $2 \%$ maltextract agar augmented with $200 \mathrm{mg} / \mathrm{l}$ each of penicillin $G$ and streptomycin sulfate (both from Serva, Heidelberg, Germany). For maintenance and submerged cultivation, YMG medium (malt extract $10 \mathrm{~g} / \mathrm{l}$, glucose $10 \mathrm{~g} / \mathrm{l}$, yeast extract $4 \mathrm{~g} / \mathrm{l}$, $\mathrm{pH}$ 5.5) was used. To solidify media, $2 \%$ agar was added. Voucher specimens and mycelial cultures of the fungus are deposited in the herbarium of the Dept. of Biotechnology, University of Kaiserslautern.

The gross morphological features of the fungus colony were determined on YMG agar. For microscopy, squares of $0.2 \%$ malt extract agar were mounted directly in water. For molecular identification, the ITS and partial 18S rDNA sequences were obtained and analyzed using the method of Köpcke et al. (2002).

\section{Fermentation and isolation}

Submerged cultures were grown in YMG medium in a 201 fermenter (Braun Biostat U) at $22^{\circ} \mathrm{C}$ with aeration (3 1/min) and agitation (120 rpm). A well grown culture $(120 \mathrm{~h}, 250 \mathrm{ml})$ in the same medium was used as inoculum. During fermentation, aliquots of the culture $(100 \mathrm{ml})$ were taken and the mycelium separated by filtration. The culture fluid was extracted twice with an equal volume of ethyl acetate and the mycelium with $100 \mathrm{ml}$ of methanol-acetone 1:1 (v/v). After evaporation of the solvents in vacuo $\left(40^{\circ} \mathrm{C}\right)$, the residues were dissolved in $1 \mathrm{ml}$ of $\mathrm{MeOH}$ and tested for cytotoxic activity against COLO-320 cells.

The fermentation was terminated after $168 \mathrm{~h}$ when the glucose had been used up. The culture fluid (18 liters) was separated from the mycelium which contained no active compound and was discarded. Hormonemate was extracted from the culture fluid by adsorption onto Mitsubishi Diaion HP 21 resin (column size $6.5 \times 50 \mathrm{~cm}$ ). Elution with 21 methanol yielded $1.06 \mathrm{~g}$ of a crude extract which was applied onto a silica gel column (Merck $60,0.063 \sim 0.2 \mathrm{~mm} ; 25 \times 2.5 \mathrm{~cm})$. Upon elution with cyclohexane/ethyl acetate $1: 1,360 \mathrm{mg}$ of an enriched product were obtained. Further purification was achieved by gel filtration on Sephadex LH 20 with methanol as eluant and by preparative HPLC (SP 250/21 Nucleosil 100-7 RP-18, $7 \mu \mathrm{m}$, $250 \times 21 \mathrm{~mm} ; \mathrm{H}_{2} \mathrm{O}$ /acetonitrile 8:92, flow $5 \mathrm{ml} /$ $\mathrm{min}$ ) yielding $20 \mathrm{mg}$ of $\mathbf{1}$.

\section{Biological assays}

The antimicrobial spectra were measured as described previously (Anke et al., 1989).

COLO-320 cells (DSMZ ACC 144, human colon adenocarcinoma), Jurkat cells (ATCC TIB 152, human acute $\mathrm{T}$ cell leukemia), MCF-7 cells (DSMZ ACC115, human breast adenocarcinoma) and HL-60 cells (ATCC CCL 240, human promyelocytic leukemia) were grown in RPMI 1640 medium supplemented with $10 \%$ fetal calf serum (FCS), $65 \mu \mathrm{g} / \mathrm{ml}$ penicillin $\mathrm{G}$ and $100 \mu \mathrm{g} / \mathrm{ml}$ streptomycin sulfate in a humidified atmosphere containing $5 \% \mathrm{CO}_{2}$ at $37{ }^{\circ} \mathrm{C}$. DLD-1 cells (ATCC CCL 221, human colon adenocarcinoma), HT-29 cells (DSMZ ACC 299, human colon adenocarcinoma), HEP-G2 cells (DSMZ ACC 180, human hepatocellular carcinoma) and HeLa S3 (ATCC CCL 2.2, human cervix carcinoma) were maintained in DMEM medium (with $10 \%$ FCS, $65 \mu \mathrm{g}$ / $\mathrm{ml}$ penicillin $\mathrm{G}$ and $100 \mu \mathrm{g} / \mathrm{ml}$ streptomycin sulfate) in a humidified atmosphere containing $5 \%$ $\mathrm{CO}_{2}$ at $37^{\circ} \mathrm{C}$.

Cytotoxicity was measured in microtiter plates with $\sim 1 \times 10^{5}$ cells $/ \mathrm{ml}$. Cells were incubated with or without the test compounds. After 24, 48 and 72 hours the cells were examined under the microscope and the percentage of lysed cells counted. In addition, the effect on the growth of monolayer cell lines was measured with Giemsa stain as described by Weber et al. (1990). The viability of cells growing in suspension was measured by a test based on XTT (2,3-bis(2-methoxy-4-nitro-5-sulfophenyl)-2H-tetrazolium-5-carboxanilide) (Roche Diagnostics, Mannheim) as described in the product information.

Induction of apoptosis was measured with a caspase-3-activity assay. The cells were seeded at a density of $5 \times 10^{5}$ cells $/ \mathrm{ml}$ in 96 -well plates (Renner) with and without the compounds to be tested. After incubation for the times indicated, cells were 
centrifuged at $1000 \times g$ for $10 \mathrm{~min}$ at $4^{\circ} \mathrm{C}$, washed with PBS and lysed with $50 \mu$ lysis buffer containing $50 \mathrm{~mm}$ HEPES (4-(2-hydroxyethyl) piperazine1-ethanesulfonic acid), 0.1\% CHAPS (3-[(3-cholamidopropyl) dimethylammonio]-1-propane sulfonate), 5 mм DTT and 0.1 mм EDTA (pH 7.4). After a freezing step at $-80{ }^{\circ} \mathrm{C}$ and rethawing, the lysate was centrifugated at $1000 \times g$ for $10 \mathrm{~min}$ at $4{ }^{\circ} \mathrm{C}$. Per well $20 \mu \mathrm{l}$ of the supernatant were incubated with $80 \mu \mathrm{l}$ of assay buffer containing $20 \mu \mathrm{M}$ fluorogenic caspase-3 substrate Ac-DEVD-amino4-methylcoumarin (Calbiochem, Bad Soden, Germany), 50 mм HEPES, $0.1 \%$ CHAPS, $10 \%$ glycerol, $100 \mathrm{~mm} \mathrm{NaCl}, 10 \mathrm{~mm}$ DTT and $0.1 \mathrm{~mm}$ EDTA (pH 7.4) for $120 \mathrm{~min}$ at $37^{\circ} \mathrm{C}$. For inhibition studies Ac-DEVD-CHO $(20 \mu \mathrm{M})$ (Calbiochem, Bad Soden, Germany) was added. AMC released from the cleavage of Ac-DEVD-AMC was measured by a spectrofluorimeter with excitation and emission wavelengths of $355 \mathrm{~nm}$ and $460 \mathrm{~nm}$ respectively.

The influence of hormonemate on the synthesis of proteins, RNA and DNA in COLO-320 cells was analyzed as described previously (Weidler et al., 2000). $10^{6}$ COLO-320 cells in $1 \mathrm{ml}$ RPMI 1640 medium supplemented with $10 \%$ fetal calf serum were seeded in 24-well plates and allowed to grow for $16 \mathrm{~h}$. The test compounds and 3700 $\mathrm{Bq}$ of $\left[2-{ }^{14} \mathrm{C}\right]$-thymidine, $\left[2-{ }^{14} \mathrm{C}\right]$-uridine or $\left[1-{ }^{14} \mathrm{C}\right]-$ leucine (all $1.8-2.2 \mathrm{GBq} / \mathrm{mmol}$ ) and the cells were incubated for an additional $24 \mathrm{~h}$. The medium was then removed and the cells were washed with icecold PBS. Then $0.5 \mathrm{ml}$ of $15 \%$ ice-cold TCA were added, the lysate collected and centrifuged at $14000 \times g$ for $10 \mathrm{~min}$ at $4{ }^{\circ} \mathrm{C}$. After washing with $1 \mathrm{ml}$ of $5 \%$ TCA, the precipitate was centrifuged again and the pellet taken up in $1 \mathrm{ml}$ of scintillation fluid (Quickszint 454). The radioactivity was measured in a liquid scintillation counter.

Nematicidal activities (Mayer et al., 1999) and phytotoxic activities towards germinating plant seeds were measured according to Anke et al. (1989).

The induction of morphological and physiological differentiation of HL-60 cells was assayed as described previously (Erkel et al., 1996). For the differentiation assay, cells were grown for 4 days with or without the test compounds. Differentiated cells reduced the water-soluble nitro-blue tetrazolium chloride (NBT) to blue-black cell-as- sociated nitro-blue diformazan deposits. For quantification the percentage of blue-black cells was determined.

\section{Results and Discussion}

\section{Identification of the producing strain}

E99156 grew rapidly on YMG agar (70 mm diameter in $10 \mathrm{~d}$ at $24^{\circ} \mathrm{C}$ ), initially as hyaline hyphae which later became densely septate and melanized, giving the culture a dark-green appearance. Yeast-like cylindrical conidia were produced successively from intercalary hyphal segments via very short papillae, of which there were only one or two per hyphal segment (Fig. 2a). These conidia were hyaline and heterogeneous in size, the usual range being $5-7 \times 2.5-3.5 \mu \mathrm{m}$, but with larger conidia (up to $10 \times 4 \mu \mathrm{m}$ ) occasionally observed. In very mature hyphae, the cell walls became thick with longitudinal as well as transverse septa (Fig. 2b). Most of these features as well as the association of E99156 with a coniferous host matched the description of Hormonema dematioides given by Hermanides-Nijhof (1977), the ex-
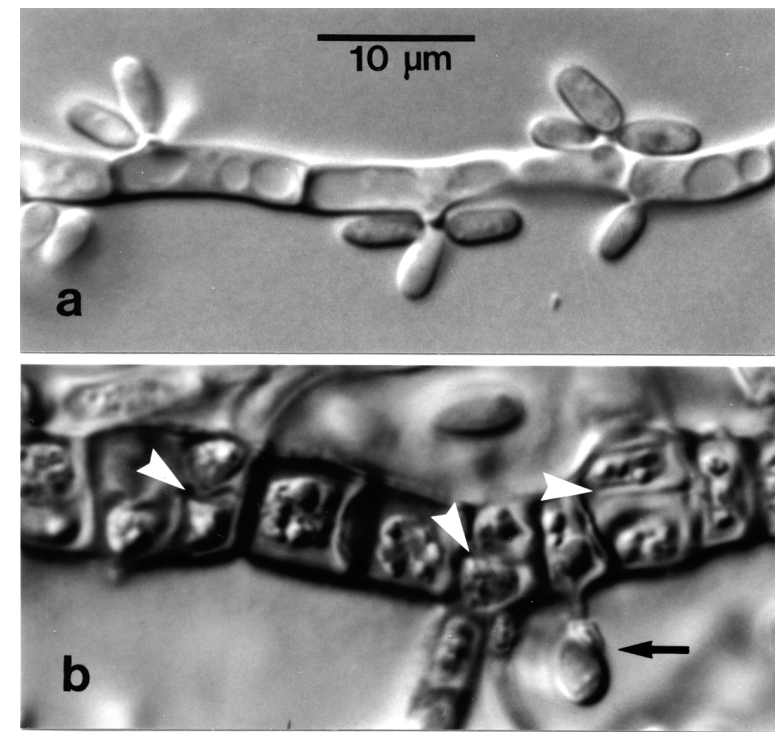

Fig. 2. Microscopic features of Hormonema dematioides E99156. (a) Young hypha, with each cell producing conidia by one short papilla. (b) Mature hypha with thick melanized walls and a high density of transverse septa and some longitudinal septa (arrowheads). Conidia were produced even by these old cells (arrow). Both images to the same scale. 
ception being the slightly smaller conidia of E99156.

Since the microscopic identification of imperfect members of the Dothideales (Ascomycota) is notoriously insecure, we performed DNA sequence analyses. From a GenBank search using the ITS sequence of the ribosomal DNA gene cluster $(622$ bp including primers ITS4 and ITS5; GenBank accession number AY253451), the five organisms with the most similar ITS sequences were Hormonema macrosporum AJ244247 (99.0\% identity), $H$. dematioides ranging from AJ278925 (98.9\%) to AF462439 (97.6\%), Aureobasidium pullulans AF423114 (98.5\%), Sclerophoma pityophila AF462438 (97.9\%), and Kabatina thujae AF013226 (94.2\%). For the partial 18S rDNA sequence of E99156 (AY253452; 788 bp), the most similar results were Delphinella strobiligena AY016341 (100\%), Dothidea ribesia AY016343, Aureobasidium pullulans M55639, Discosphaerina fagi AY016342 (all 99.4\%), and Dothidea insculpta U42474 (99.2\%). The assignment of E99156 to the Dothideales (Ascomycota) was unambiguous on the basis of the $18 \mathrm{~S}$ rDNA analysis, the non-appearance of Hormonema in the search results being due to the lack of published $18 \mathrm{~S}$ sequences for that genus. The analysis of the much more variable ITS sequence supported the microscopic identification of E99156 as $H$. dematioides because the difference between the ITS sequence of E99156 and that of the most similar H. dematioides isolate AJ278925 (6 base changes) was less than that between the various $H$. dematioides sequences available (up to 7 differences; data not shown). Further, H. macrosporum, whose ITS sequence had the closest similarity with that of E99156, is now considered to be synonymous with $H$. dematioides (de Hoog et al., 1999; Yurlova et al., 1999). Large infraspecific variations of ITS sequences are somewhat unusual for Ascomycota except for the genera Aureobasidium and Hormonema (Yurlova et al., 1999), but have also been described for Cunninghamella (Zygomycota) by Liu et al. (2001).

\section{Fermentation and isolation}

The production of hormonemate (1) by strain E99156 in 201 batches started $24 \mathrm{~h}$ after inoculation. The highest cytotoxic activity of the crude extracts from the culture broth against COLO-320 was reached when the glucose was used up after approximately 6 days. The extraction and isolation of hormonemate is described in the experimental section.

\section{Biological properties}

Cytotoxic activity of hormonemate was observed against all tested cancer cell lines with $\mathrm{IC}_{50}$ values of $3.5-7.5 \mu \mathrm{g} / \mathrm{ml}$ for COLO-320, DLD-1, HT-29, Jurkat and HL-60 cells. Hep-G2 and HeLa S3 cells were less sensitive with an $\mathrm{IC}_{50}$ of 9$10 \mu \mathrm{g} / \mathrm{ml}$ (Table I). As measured by NBT reduction, 1 induced $17-20 \%$ of HL-60 cells to differentiate at concentrations of $5 \mu \mathrm{g} / \mathrm{ml}$ (Table II).

In our studies hormonemate proved to be a strong inducer of apoptosis in COLO-320 cells, leading to morphological changes such as cell shrinkage and the formation of apoptotic bodies already after two hours of incubation. To investigate the apoptotic cascade activation initiated by $\mathbf{1}$, COLO-320 cells were exposed to $\mathbf{1}$ in several concentrations and incubated for the times indicated. Caspase-3 activity significantly increased in response to $\mathbf{1}$ in a time- and concentration-dependent manner (Fig. 3), and it was strongly inhibited by the caspase- 3 inhibitor Ac-DEVD-CHO

Table I. Cytotoxic activities of hormonemate.

\begin{tabular}{lcccc}
\hline Cell line & \multicolumn{3}{c}{ Hormonemate LD } & \multicolumn{2}{c}{ Hormonemate LD } \\
& {$[\mu \mathrm{g} / \mathrm{ml}]$} & {$[\mu \mathrm{M}]$} & {$[\mu \mathrm{g} / \mathrm{ml}]$} & {$[\mu \mathrm{M}]$} \\
\hline COLO-320 & 6 & 8 & 10 & 13 \\
HEP-G2 & 10 & 13 & 17.5 & 23 \\
HeLa S3 & 9 & 12 & 14 & 19 \\
Jurkat & 6 & 8 & 9 & 12 \\
HL-60 & 3.5 & 5 & 7 & 9 \\
DLD-1 & 7.5 & 10 & 10 & 13 \\
MCF-7 & 7.5 & 10 & 10 & 13 \\
HT-29 & 6 & 8 & 9 & 12 \\
\hline
\end{tabular}

Table II. Differentiation of HL-60 cells after 96 hours of incubation. Metabolic activity was measured by an XTTbased colorimetric assay (Roche Diagnostics, Mannheim).

\begin{tabular}{lccc}
\hline Compound & & $\begin{array}{c}\text { Differentiated } \\
\text { cells (\%) }\end{array}$ & $\begin{array}{c}\text { Metabolic } \\
\text { activity (\%) }\end{array}$ \\
\hline Negative control & - & $6-8$ & 185 \\
$\mathbf{1}$ & $3.5 \mu \mathrm{g} / \mathrm{ml}$ & $17-20$ & 143 \\
DMSO & $1 \%(\mathrm{v} / \mathrm{v})$ & $70-80$ & 100 \\
\hline
\end{tabular}


(Fig. 4). This shows that the cleavage of AcDEVD-AMC and the resulting fluorescence signal were due to caspase-3 activity.

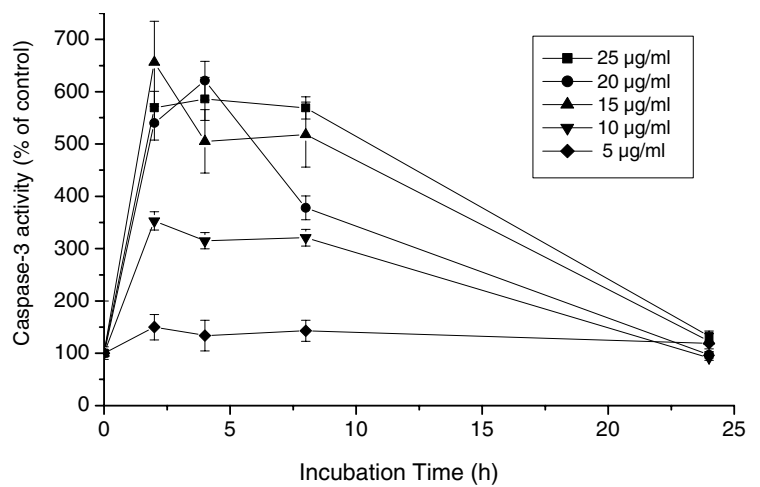

Fig. 3. Time course of apoptosis induction by $\mathbf{1}$ as measured by the caspase activity assay. COLO-320 cells were treated with and without hormonemate. After incubation followed by lysis of the cells, $20 \mu \mathrm{m}$ Ac-DEVDAMC was added as a fluorogenic substrate. AMC released from Ac-DEVD-AMC was measured by a spectrofluorimeter with excitation and emission wavelengths of $355 \mathrm{~nm}$ and $460 \mathrm{~nm}$ respectively.

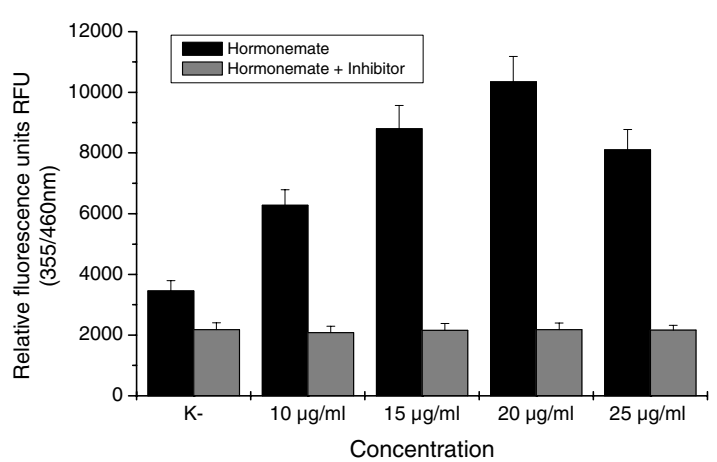

Fig. 4. Induction of apoptosis by $\mathbf{1}$ as measured by the caspase activity assay. COLO-320 cells were treated with and without hormonemate. After four hours of incubation followed by lysis of the cells, $20 \mu \mathrm{M}$ Ac-DEVDAMC was added as a fluorogenic substrate. AMC released from Ac-DEVD-AMC was measured by a spectrofluorimeter with excitation and emission wavelengths of $355 \mathrm{~nm}$ and $460 \mathrm{~nm}$ respectively. In addition, fluorescence of controls and drug-treated samples was measured in the presence of the caspase- 3 inhibitor AcDEVD-CHO $(20 \mu \mathrm{M})$.

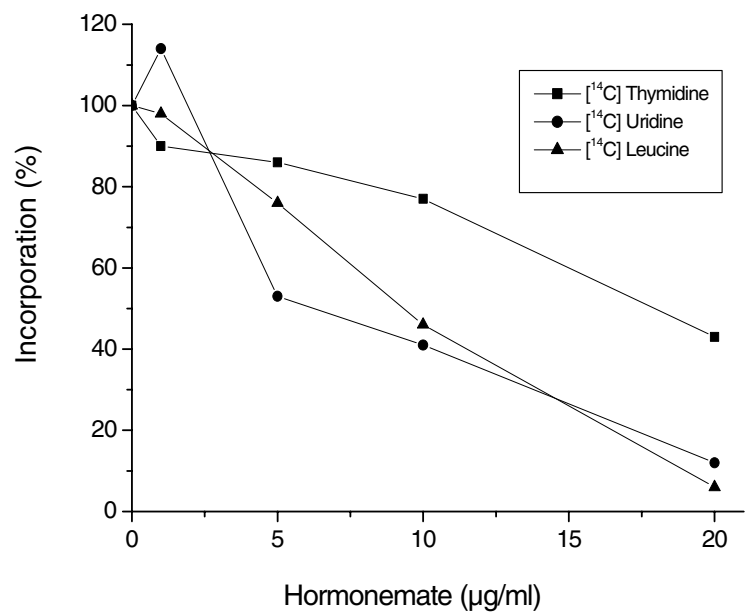

Fig. 5. Incorporation of radiolabelled precursors into macromolecules of COLO-320 cells. The influence of hormonemate on cellular DNA-, RNA-, and protein synthesis was measured in COLO-320 cells by determining the incorporation of $\left[{ }^{14} \mathrm{C}\right]$-thymidine, $\left[{ }^{14} \mathrm{C}\right]$-uridine and $\left[{ }^{14} \mathrm{C}\right.$-leucine in TCA-insoluble fractions (Weidler $e t$ al., 2000). Controls (100\%): Thymidine $144.4 \mathrm{~Bq}$, uridine $214.8 \mathrm{~Bq}$, leucine $144.3 \mathrm{~Bq}$.

Cellular DNA-, RNA-, and protein synthesis was measured in COLO-320 cells by determining the incorporation of $\left[{ }^{14} \mathrm{C}\right]$-thymidine, $\left[{ }^{14} \mathrm{C}\right]$-uridine and $\left[{ }^{14} \mathrm{C}\right]$-leucine in TCA-insoluble fractions (Fig. 5). The uptake of uridine into RNA was most sensitive $(50 \%$ inhibition at $5-6 \mu \mathrm{g} / \mathrm{ml})$.

No antifungal (Penicillium notatum, Mucor miehei, Paecilomyces variotii, Nematospora coryli), antibacterial (Bacillus subtilis, Enterobacter dissolvens, Micrococcus luteus), phytotoxic (Lepidium sativum, Setaria italica) and nematicidal (Meloidogyne incognita, Caenorhabditis elegans) activities were observed for $\mathbf{1}$ at concentrations of $50 \mu \mathrm{g}$ per $\mathrm{ml}$ or filter paper disk with the exception of Bacillus brevis which showed an inhibition zone of $8 \mathrm{~mm}$ at a concentration of $50 \mu \mathrm{g} /$ disk.

\section{Acknowledgements}

Financial support from Zentaris AG (Frankfurt/ Main, Germany) is gratefully acknowledged. 
Anke H., Bergendorf O., and Sterner O. (1989), Assays of the biological activities of guaiane sesquiterpenes isolated from fruit bodies of edible Lactarius species. Food Chem. Toxicol. 27, 393-397.

de Hoog G. S., Zalar P., Urzì C., de Leo F., Yurlova N. Y., and Sterflinger K. (1999), Relationships of dothideaceous black yeasts and meristematic fungi based on 5.8S and ITS2 rDNA sequence comparison. Stud. Mycol. 43, 31-37.

Erkel G., Becker U., and Anke T. (1996), Nidulal, a novel inducer of differentiation of human promyelocytic leukemia cells from Nidula candida. J. Antibiot. 49, 1189-1195.

Hawksworth D. L. (1991), The fungal dimension of biodiversity: magnitude, significance, and conservation. Mycol. Res. 95, 641-655.

Hermanides-Nijhof E. J. (1977), Aureobasidium and allied genera. Stud. Mycol. 15, 141-177.

Köpcke B., Weber R. W. S., and Anke H. (2002), Galiellalactone and its biogenetic precursors as chemotaxonomic markers of the Sarcosomataceae (Ascomycota). Phytochemistry 60, 709-714.
Liu X.-Y., Huang H., and Zheng R.-Y. (2001), Relationships within Cunninghamella based on sequence analysis of ITS rDNA. Mycotaxon 80, 77-95.

Mayer A., Kilian M., Hoster B., Sterner O., and Anke $\mathrm{H}$. (1999), In vitro and in vivo nematicidal activities of the cyclic dodecapeptide omphalotin A. Pest. Sci. $\mathbf{5 5}, 27-30$.

Strobel G. A. (2002), Rainforest endophytes and bioactive products. Crit. Rev. Biotechnol. 22, 315-33.

Weber W., Anke T., Stefan B., and Steglich W. (1990), Antibiotics from basidiomycetes. XXXII. Strobilurin E: A new cytostatic and antifungal $E$ - $\beta$-methoxyacrylate antibiotic from Crepidotus fulvotomentosus. J. Antibiot. 43, 207-212.

Weidler M., Rether J., Anke T., and Erkel G. (2000), Inhibition of interleukin-6 signaling by galiellalactone. FEBS Lett. 484, 1-6.

Yurlova N. A., de Hoog G. S., and Gerrits van den Ende A. H. G. (1999), Taxonomy of Aureobasidium and allied genera. Stud. Mycol. 43, 63-69. 